DOI: 10.33184/YVDK-2021-04-30.9

И.Ф. Мухаметова (асc. БашГУ, г. Уфа)

\title{
ОСОБЕННОСТИ ПЕРЕВОДА НАИМЕНОВАНИЙ ТЕРМИНОВ РОДСТВА С РУССКОГО ЯЗЫКА НА КИТАЙСКИЙ ЯЗЫК
}

Статья посвящена исследованию наименований терминов родства в китайском языке и особенностям их перевода с русского языка на китайский язык. В статье рассматриваются проблемы перевода различных наименований терминов родства в художественном тексте, проводится анализ перевода терминов родства в романе И.С. Тургенева «Отиьь и дети» на китайский язык.

Ключевые слова: наименования терминов родства, китайский язык, русский язык.

The article is devoted to the study of kinship terms in Chinese. This article discusses and analyzes the peculiarities of the translation of kinship terms from Russian into Chinese in a literary text precisely in the novel by I.S. Turgenev "Fathers and Sons".

Key words: kinship terms, relation and relation in law terms, Chinese language, Russian language.

Статья посвящена сопоставительному анализу русских и китайских наименований терминов родства, как кровного, так и некровного. Актуальность данного исследования определяется тем обстоятельством, что перевод наименований терминов родства с русского языка на китайский язык является малоизученной проблемой в настоящее время. Новизна заключается в том, что в ней впервые анализируются особенности передачи терминов родства с русского языка на китайский язык на материале художественного текста романа И.С. Тургенева «Отцы и дети» и текста перевода, выполненного китайским писателем и переводчиком Ба Цзинем 巴金《父与子》. Целью исследования является сравнительный анализ терминов родства 
двух разноструктурных языков и выявление особенностей их передачи при переводе с русского языка на китайский язык.

Каждый язык имеет свой собственный способ кодирования концепций реального мира, который имеет глубокую связь с национальной культурой [Хуан и Цзя, 2017:412]. Хотя каждый язык способен обозначать все мыслимые родственные отношения, не всегда удается найти прямые эквивалентные родственные термины в разных языках. Отражая культурное значение семейных отношений в китайском обществе, китайский язык содержит множество конкретных терминов родства, которые облегчают точную классификацию отношений между членами семьи. Действительно, китайская система родства уходит корнями глубоко в китайскую культуру. Это продукт столетий развития «сельскохозяйственного общества, экономики, ориентированной на семью, и строго иерархической семейной системы» [Хуан и Цзя, 2017: 413].

Китайские термины родства являются важной составляющей китайской культуры. В самом деле, они играли важную роль в создании и поддержании китайской культуры на протяжении всей истории Китая и до сих пор имеют такое же значение в повседневной жизни людей в современном китайском обществе. Они являются частью уникальной особенности, которая отличает китайский язык и культуру от других. Лингвистически, это проявляется в узкой семантической структуре терминов родства, что является отличительной чертой китайского языка в сравнении с западными аналогами. В китайском языке, с одной стороны, есть две группы наименований обращения к соответствующим родственникам, происходящим от матери и отца, или родственных отношений, которые отражают точное положение родственников в структуре семьи, например tang ge и biao ge. Здесь tang ge означает старшего двоюродного брата по отцовской линии, a biao ge означает старшего двоюродного брата по материнской линии. В русском языке, напротив, эти две группы названий обычно объединены в единую, отражающую только иерархию поколения и пола. Как показывает этот пример, семантическая концептуальная структура родства в разных языках представляет интерес для сравнительных исследований.

Многие китайские термины родства не имеют соответствующих терминов в русском языке; они должны быть 
перефразированы в переводе. Многообразие родственных обозначений в китайском языке часто вызывает затруднения при переводе как с китайского на русский язык, так и с русского на китайский. Ниже мы рассмотрим некоторые характерные особенности китайской структуры родства и передачи наименований терминов родства при переводе с русского языка на китайский язык.

В отличие от русских терминов родства, которые сосредоточены на прямых линейных отношениях, таких как отец, мать и т.д., в китайском языке в этом отношении более богатый набор терминов родства, точно определяющий широкий спектр родственных отношений. Каждый из этих терминов имеет довольно узкое значение, определяя небольшую область семантического пространства родства. Например, «дядя» в русском языке относится к брату или зятю одного из родителей; в китайском языке существует пять терминов для различных аспектов наименований дяди: бо фу (старший брат отца), шу фу (младший брат отца), гу фу (муж сестры отца), изю фу (брат матери) и ю фу (муж сестры матери), каждый из которых обозначает разные отношения.

Из этого следует, что в китайских родственных обозначениях большую роль играет разделение членов семьи по старшинству, например: «А что дядя? здоров?» (оригинал)/ “伯伯怎样? 身体好吗?” (перевод). Русское «дядя» в китайском языке имеет два наименования: 伯父 bofu/ 伯伯bobo - это старший брат отца и叔父shufu / 叔叔shushu - младший брат отца. В данном случае переводчик верно подобрал наименование伯伯bobo при обращении к дяде, а именно, к Павлу Петровичу Кирсанову, старшему брату Николая Кирсанова. При переводе наименований терминов родства с русского языка на китайский язык основная трудность заключается в том, что оригинал не несет дополнительной информации (по критерию старшинства), а в переводе на китайский язык, ввиду отсутствия в языке перевода эквивалента, не обремененного дополнительной «смысловой наполненностью», так или иначе ее приобретает [Морозкина, Чжао Паньпань 2019: 680].

Русское наименование «брат», в свою очередь, также делится на 哥哥gege (старший брат) и 弟弟idi ( младший брат), 
так же, как и сестра - на 姐姐jiejie (старшая сестра) и 妹妹meimei (младшая сестра). Например: «Николай Петрович родился на юге России, подобно старшему своему брату Павлу» (оригинал)/ “古拉·彼得罗维奇生在俄罗斯南方, 同他哥哥帕维尔一样”

(перевод). В тексте оригинала изначально есть указание на старшинство брата, поэтому при переводе не возникакет трудности при подборе соответствующего эквивалента 哥哥gege.

Более того, в китайском языке зачастую есть несколько синонимов, относящихся к единой концепции родства. Например, существует более пяти китайских терминов родства, относящихся к отцу (爸爸baba, 父亲fuqin, 老爸laoba, 爹die и 老子laozi). Различия между ними в основном заключаются в различных значениях, таких как степень родства между отцом и его потомством, разговорная речь и т.д. Однако похожие синонимы родства существуют и в русском языке, например, мать, мама и мамочка. В этом аспекте русская система родства превышает китайскую количественно за счет производных суффиксальных компонентов.

Интерес представляет следующий пример передачи наименований родства: «Он без нужды растягивал свою речь, избегал слова «папаша» и даже раз заменил его словом «отец»» (оригинал)/

“避免使用“爸爸”这个字眼，甚至有一回他改口为“父亲”当然, 说的时候含含糊糊的, 像是从齿缝里发出的。” (перевод). В данном примере стилистически окрашенное слово «папаша» передается наименованием 爸爸baba (папа), используемым в более неформальном контескте, а «отец» соответствующим аналогом父亲fuqin (отец), которое более употребительно в формальной обстановке. Здесь перед переводчиком стоит важная задача - «передать красоту содержания и стиля оригинала, не утрачивая его художественных особенностей» [Морозкина, Чжао Паньпань 2018: 230].

Отличительной особенностью китайской системы родства является тот факт, что на наименование того или иного родственника влияет то, с чьей стороны имеется родство - со стороны отца или же матери. Например, дедушка и бабушка со стороны отца - это爷爷 уеуе и 奶奶 nainai, по линии матери - 
это外公 waigong и 外婆waipo, соответственно; 孙子 sunzi - внук (сын сына) и 外孙 waisun - внук (сын дочери); 曾孙女 zengsunnü это правнучка (внучка по линии сына)» и 外曾孙女 waizengsunnü - правнучка (внучка по линии дочери) и т. д. Стоит отметить, что материнский маркер wai на китайском буквально означает «вне», что подразумевает маргинальный социальный статус, приписываемый материнским отношениям в китайской традиции.

В русском языке отсутствует такой детализированный терминологический механизм, позволяющий различать сложные отношения, порожденные браком. Это может отражать русскую культуру, в которой различия между кровными и родственными отношениями имеют меньшее значение. Следовательно, при переводе данных терминов родства необходимо установить родство (по стороне матери или по стороне отца), для того чтобы верно передать значение того или иного наименования, поскольку дополнительное «смысловое наполнение родственных наименований в китайском языке порой может быть весьма важным» [Болсуновская, 2015:1097].

Рассмотрев некоторые особенности передачи наименований терминов родства двух разноструктурных языков, можно сделать вывод, что перевод данных наименований на китайский язык вызывает определенные трудности, которые обусловлены существенными структурными различиями данной пары языков и особенностями культуры. Китайскую систему родства отличает большая детализированность и разветвленность, где каждый термин отражает отношений, пола и поколения. Русские наименования терминов родства более обобщенные и не такие детальные. Как упоминалось ранее, зачастую невозможно подобрать эквивалентные термины в этих двух языках, ввиду их отсутствия. В частности, при переводе на китайский язык в некоторых русских родственных наименованиях должна быть устранена неоднозначность с точки зрения возраста, пола или линии родства и прочее.

\section{ЛИТЕРАТУРА}

1. Болсуновская, Ю. А. Трудности перевода названий степеней родства и имен собственных с китайского 
на русский язык и наоборот // Молодой ученый. 2015. № 8 (88). — С. 1097-1099. [Электронный pecypc]. URL: https://moluch.ru/archive/88/17723/ (дата обращения: 28.04.2021).

2. Морозкина Е. А., Чжао Паньпань. Особенности сочетаемости иероглифов в китайской классической поэзии и проблема перевода//Научный журнал "Доклады Башкирского университета". 2019. Вып. 4, № 6. С. 679-685.

3. Морозкина E. А., Чжао Паньпань. Перевод китайской классической поэзии в России и за рубежом: К истории вопроса// Вестник Башкирского университета. 2018. Т. 24. №1. С. 229-233.

4. Тургенев И.С. Отцы и дети. М.: Детская литература. 2002. C. 4-17.

5. Huang, S. and W. Jia (2000) "The Cultural Connotations and Communicative Functions of Chinese Kinship Terms". American Communication Journal Vol.3, No 3. - S. 412-413.

6.《屠格涅夫全集・父与子》。巴金译. 北京, 2001. Ба Цзинь. Тургенев И.С. Соч. в 6 т. Т. 3: Отцы и дети / Перевод. Пекин, 2001 .

(C) Мухаметова И.Ф., 2021 г. 